\title{
PEMASARAN GARAM RAKYAT (Studi Kasus Desa Lembung, Kecamatan Galis, Kabupaten Pamekasan, Jawa Timur)
}

\author{
Ahmad Syariful Jamil'), dan Netti Tinaprilla ${ }^{2)}$ \\ ${ }^{1,2}$ Departemen Agribisnis, Fakultas Ekonomi dan Manajemen, Institut Pertanian Bogor \\ 1)ahmadsyarifuljamil@gmail.com
}

\begin{abstract}
Salt is a strategic and high economic valued commodity because it is needed in every human food as a main raw material. The purpose of this research was to analyze marketing channels, function, structure and marketing institutions of farmer salt commodity and to analyze the efficiency of farmer salt marketing in any marketing channel using marketing margin, farmer's share and benefit cost ratio approach. The research showed that there were main channels, the formation of which was based on the starting point of the distribution with different institutions, functions and market structure in each channel. The result of operational efficiency analysis indicator and qualitative indicator showed that all marketing channels were inefficient. This was due to the fact that farmers had a role as a price taker and price fixing tended to be unfair because farmer had a weak bargaining power. Thus, goverment role was hoped to change farmers 'roles and improve the presence of farmer groups to increase farmer prosperity.
\end{abstract}

Keyword(s): salt, efficiency, farmer's share, salt marketing

\begin{abstract}
ABSTRAK
Garam merupakan komoditi strategis dan bernilai ekonomis tinggi. Tujuan dilakukannya penelitian ini adalah menganalisis saluran pemasaran, fungsi pemasaran, struktur, dan perilaku pasar oleh lembaga-lembaga pemasaran pada komoditi garam rakyat dan menganalisis efisiensi saluran pemasaran garam rakyat pada setiap saluran pemasaran dengan pendekatan marjin pemasaran, farmer's share, dan rasio keuntungan. Berdasarkan hasil penelitian, terdapat tiga saluran utama yang terbentuk didasarkan pada titik awal penyaluran dengan lembaga, fungsi, dan struktur pasar yang berbeda pada setiap salurannya. Hasil indikator analisis efisiensi operasional dan indikator kualitatif menunjukkan bahwa saluran pemasaran yang terbentuk belum efisien. Hal tersebut diakibatkan karena petani masih berperan sebagai penerima harga dan kecenderungan pemberian harga yang tidak adil karena posisi tawar petani rendah. Oleh karena itu, peran pemerintah diharapkan dapat mengubah peran petani dan mendorong adanya kelompok tani untuk meningkatkan kesejahteraan petani.
\end{abstract}

Kata Kunci: garam, efisiensi, farmer's share, pemasaran garam

\section{PENDAHULUAN}

Garam merupakan komoditi strategis yang dibutuhkan manusia dalam empat bentuk yaitu garam konsumsi, aneka pangan, aneka industri, dan garam industri Chlor Alkali Plant (CAP) untuk pembuatan plastik Polivinil Chlor (PVC). Garam sebagai produk yang diproduksi dari lahan tambak merupakan salah satu komoditi yang selalu dibutuhkan manusia 
sejalan dengan kebutuhan manusia terhadap makanan. Berdasarkan Kementerian Kelautan dan Perikanan (2010), setiap orang mengonsumsi lebih kurang empat kg garam per tahun dalam bentuk aneka pangan. Oleh karena itu, diperkirakan kebutuhan garam akan meningkat seiring dengan bertambahnya jumlah penduduk, pertumbuhan industri Chlor alkali Plant (CAP), serta industri lainnya yang membutuhkan garam.

Peluang peningkatan kebutuhan yang begitu besar tersebut belum dapat dimanfaaatkan oleh berbagai stakeholder dalam bidang pergaraman nasional. Hal ini terlihat dari produksi garam nasional yang masih belum mampu memenuhi kebutuhan nasional. Produksi garam domestik hingga saat ini tidak mampu mengimbangi peningkatan kebutuhan garam. Produksi domestik hanya mampu memasok sekitar 30-35 persen dari total kebutuhan nasional dan itu pun hanya terbatas untuk garam konsumsi (Rochwulaningsih 2013). Hal ini disebabkan belum terpenuhinya standar garam industri yang membutuhkan kandungan $\mathrm{NaCl}$ yang tinggi.

Ketidakseimbangan antara kebutuhan garam dengan kapasitas produksi garam nasional tersebut mendorong pemerintah untuk melakukan impor garam. Menurut Kamar Dagang Indonesia, Indonesia sangat tergantung terhadap garam impor baik secara kualitas maupun kuantitas dan memiliki kecenderungan yang meningkat. Petani sebagai produsen garam utama seakan kurang bergairah dalam meningkatkan produksinya baik secara kuantitas maupun kualitas. Hal ini diduga akibat berbagai permasalahan yang melingkungi bidang pergaraman khususnya pada sistem pemasaran.

Sistem pemasaran garam Indonesia diduga relatif tidak efisien dan cenderung memberatkan petani garam. Pernyataan tersebut didukung oleh pernyataan Kementerian Kelautan dan Perikanan (2011) bahwa struktur pergaraman pada sektor hulu didominasi oleh petani yang berskala kecil (terfragmentasi) dengan jumlah petani yang besar serta kelembagaan petani yang relatif lemah menyebabkan petani tidak memliki posisi tawar yang kuat dalam rantai atau saluran pemasaran. Sebaliknya pada sektor hilir didominasi oleh industri skala besar dengan jaringan yang kuat, sehingga ketidakseimbangan tersebut membuat keuntungan dalam saluran pemasaran lebih dinikmati oleh industri hilir.

Ketidakseimbangan posisi tawar tersebut berpengaruh terhadap perilaku industri yang tercermin dalam proses pemasaran garam. Pada proses pemasaran, petani seakan-akan hanya bertindak sebagai produsen garam tanpa memiliki kekuatan dalam penentuan mutu maupun harga. Dimana hal ini disebabkan oleh terbatasnya akses informasi yang dimiliki petani. Kondisi tersebut diperparah dengan fakta bahwa sarana dan prasarana yang minim, serta lahan garam yang berada di pinggir pantai dengan lokasi terpencil menyebabkan biaya pemasaran (after farm gate) semakin besar.

Konsekuensi dari berbagai kondisi di atas menyebabkan marjin pemasaran pergaraman besar, sedangkan bagian yang didapatkan petani relatif kecil. Hal 
tersebut dikonfirmasi oleh Direktorat Jenderal Kelautan dan Pulau-Pulau Kecil (KP3K) mengungkapkan bahwa marjin pemasaran garam sangat besar dimana pada tingkat retail harga garam rata-rata sebesar Rp 6000/kg sedangkan ditingkat petani sentra dihargai sebesar RP $350 / \mathrm{kg}^{1}$. Selain itu, Suherman et al (2011) menambahkan bahwa petani menghadapi saluran pemasaran yang panjang sedangkan share yang diterima relatif sangat kecil.

Oleh karena itu kondisi eksisting efisiensi pemasaran menjadi sangat penting dikaji untuk memberikan gambaran keragaan sektor pergaraman. Dimana pada akhirnya hasil tersebut akan memberikan rujukan pada pemerintah dalam pengambilan kebijakan terkait pergaraman. Berdasarkan latar belakang tersebut, penelitian ini bertujuan untuk menganalisis efisiensi pemasaran garam rakyat di Desa Galis, Kecamatan Galis, Kabupaten Pamengkasan dengan pendekatan marjin pemasaran, farmer's share, dan rasio keuntungan.

\section{KERANGKA PEMIKIRAN}

\section{Konsep Saluran Pemasaran}

Saluran pemasaran merupakan rangkaian lembaga-lembaga pemasaran yang dilalui barang dalam penyalurannya dari produsen ke konsumen.

\section{Fungsi Pemasaran dan Lembaga Pemasaran}

Lembaga pemasaran merupakan individu atau badan usaha yang berperan dalam suatu sistem pemasaran suatu komoditi tertentu, yang melakukan berbagai fungsi-fungsi pemasaran. Menurut Asmarantaka (12012), terdapat tiga fungsi pemasaran yaitu fungsi pertukaran (berfokus pada perpindahan hak milik barang atau jasa), fungsi fisik (kegiatan yang secara langsung berhubungan dengan barang atau jasa) dan fungsi fasilitas (kegiatan yang memperlancar atau memfasilitasi kegiatan pemasaran).

\section{Konsep Struktur Pasar}

Struktur pasar adalah dimensi yang menjelaskan sistem pengambilan keputusan oleh pengusaha dalam perusahaan maupun industri, jumlah perusahaan dalam suatu pasar. Menurut Dahl dan Hammond (1977), terdapat 4 faktor yang menentukan struktur pasar yaitu kondisi atau keadaan produk, syarat keluar masuk pasar serta informasi pasar yang dimiliki oleh pelaku pasar.

\section{Perilaku Pasar}

Menurut Dahl and Hammond (1977) perilaku pasar adalah pola tingkah laku dari lembaga pemasaran yang menyesuaikan dengan struktur pasar yang lembaga tersebut melakukan kegiatan pembelian dan penjualan, penentuan harga dan kerjasama antara lembaga pemasaran.

\section{Konsep Efisiensi Tataniaga}

Efisiensi dalam pemasaran dapat diukur melalui dua cara, yaitu efisiensi harga dan efisiensi operasional.. Menurut Dahl dan Hammond (1977), efisiensi operasional menggambarkan biaya minimum yang dapat dicapai dalam pelaksanaan fungsi dasar pemasaran.

\footnotetext{
${ }^{1}$ http://finance.detik.com/read/2012/01/09/180613/1810831/1036/harga-garam-di-konsumen-rp-6000-kg-petani-cumadihargai-rp-750-kg [akses 18 Desember 2013]
} 
Menurut Asmarantaka (2012) menyatakan bahwa pendekatan efisiensi harga dapat didekati melalui analisis tingkat keterpaduan pasar, sedangkan pendekatan efisiensi operasional melalui marjin pemasaran, farmer's share dan biaya pemasaran.

\section{Marjin Pemasaran}

Menurut Dahl dan Hammond (1977) mendefinisikan marjin tataniaga sebagai perbedaan harga di tingkat petani dengan harga pedagang pengecer.

\section{Farmer's Share}

Farmer's share merupakan bagian yang diterima petani yang didekati dengan pembagian antara harga yang berlaku di tingkat retail terhadap harga di tingkat petani.

\section{Rasio Keuntungan dan Biaya}

Rasio keuntungan dan biaya tataniaga mendefinisikan besarnya keuntungan yang diterima atas biaya pemasaran yang dikeluarkan. Dengan demikian semakin meratanya penyebaran rasio keuntungan dan biaya, maka dari segi operasional sistem pemasaran semakin efisien (Limbong dan Sitorus, 1987).

\section{METODE PENELITIAN}

Penelitian dilakukan di wilayah Pamekasan yaitu Desa Lembung, Kecamatan Galis, Kabupaten Pamekasan. Pemilihan lokasi ini dilakukan dengan pertimbangan karena daerah tersebut merupakan salah satu sentra produksi garam rakyat terbesar di Kabupaten Pamekasan. Waktu penelitian dilakukan bulan Agustus-Februari 2014.
Metode pengumpulan data primer dilakukan melalui wawancara langsung kepada petani responden dengan menggunakan kuesioner. Penentuan responden petani dilakukan secara purposive dengan mendatangi gudang-gudang garam petani yang didampingi oleh aparatur Desa Lembung. Petani responden berjumlah 45 orang yaitu petani Desa Lembung yang melakukan pemanenan garam pada musim garam tahun 2013 Penarikan sampel untuk lembaga tataniaga dilakukan dengan metode snowball sampling, yaitu berdasarkan informasi dari responden sebelumnya.

Metode pengolahan data yang digunakan dalam penelitian ini adalah analisis kualitatif dan analisis kuantitatif. Proses analisis data kualitatif menggambarkan secara deskriptif yang terdiri dari saluran pemasaran, fungsi-fungsi pemasaran serta struktur dan perilaku pasar. Analisis data kuantitatif dalam penelitian ini dipergunakan analisis efisiensi operasional yang terdiri dari analisis marjin pemasaran, farmer's share dan rasio keuntungan dan biaya.

\section{Analisis Marjin Pemasaran}

Analisis marjin pemasaran dapat dihitung dengan pengurangan harga penjualan dengan harga pembelian pada setiap lembaga pemasaran. Secara matematik perhitungan marjin pemasaran sebagai berikut (Asmarantaka 2012):

$$
\mathbf{M T}=\mathbf{P r}-\mathbf{P f}
$$

Keterangan:

$\mathrm{MT}=$ Marjin pemasaran total $(\mathrm{Rp} / \mathrm{kg})$;

$\mathrm{Pr}=$ Harga di tingkat retail $(\mathrm{Rp} / \mathrm{kg})$;

$\mathrm{Pf}=$ Harga produsen $(\mathrm{Rp} / \mathrm{kg})$ 


\section{Analisis Farmer's Share}

Besarnya nilai bagian petani dipengaruhi oleh tingkat pengolahan, keawetan produk, ukuran produk, jumlah produk dan biaya produksi. Farmer's share dapat dihitung berdasarkan rumus :

$$
\text { Farmer's Share }=\operatorname{Pf} / \operatorname{Pr} \times 100 \%
$$

Keterangan:

$\mathrm{Pr}=$ harga di tingkat retail $(\mathrm{Rp} / \mathrm{kg})$;

$\mathrm{Pf}=$ harga di tingkat petani $(\mathrm{Rp} / \mathrm{kg})$.

\section{Analisis Rasio Keuntungan dan Biaya}

Rasio keuntungan dan biaya pemasaran setiap lembaga tataniaga dapat dirumuskan sebagai berikut (Limbong dan Sitorus, 1987):

\section{Rasio Keuntungan dan Biaya $=\pi / \mathrm{c}$}

Keterangan:

$\pi=$ keuntungan;

$\mathrm{c}=$ biaya pemasaran.

\section{ANALISIS LEMBAGA} PEMASARAN

a. Petani merupakan masyarakat Desa Lembung yang melakukan usahatani garam rakyat pada musim garam tahun 2013.

b. Pedagang pengumpul adalah lembaga pemasaran yang merupakan individu yang berperan sebagai perantara antara petani dan perantara pabrik.

c. Petani sekaligus pedagang merupakan individu yang mempunyai peran ganda. Lembaga tersebut selain melakukan fungsi seperti pedagang pengumpul juga memiliki lahan tambak yang memproduksi garam sehingga bertindak sebagai petani. d. Perantara pabrik (bandul) adalah individu yang merupakan orang kepercayaan yang ditunjuk pabrik garam untuk menerima garam rakyat yang dijual oleh pedagang pengumpul.

e. Pabrik garam merupakan lembaga pemasaran dan umumnya berbentuk PT yang berperan mengubah garam rakyat (garam krosok) menjadi garam halus yang beryodium.

f. Petani, pengumpul sekaligus pemilik Unit Pengolahan Garam Rakyat (UPGR) merupakan lembaga yang mempunyai beberapa fungsi gabungan.

g. Agen adalah lembaga pemasaran yang menjual produk garam beriodium yang siap di konsumsi.

h. Pedagang pengecer merupakan lembaga pemasaran yang membeli garam beriodium dari agen untuk kemudian dijual kembali kepada konsumen akhir.

\section{IDENTIFIKASI FUNGSI PEMASARAN}

\section{Fungsi Pemasaran di Tingkat Petani}

Secara umum petani garam responden melakukan ketiga fungsi pemasaran dalam memasarkan garamnya. Fungsi pertukaran yang dilakukan oleh petani berupa kegiatan penjualan ke pedagang pengumpul, petani-pengumpul dan petani-pengumpul-UPG. Fungsi fisik yang dilakukan oleh petani dalam memasarkan garam yaitu kegiatan penyimpanan, pengangkutan dan pengemasan. Kegiatan pengangkutan tidak dilakukan oleh petani tetapi dilakukan oleh buruh angkut (pengumbal), tetapi yang membayar adalah petani. Pengumbal tersebut 
dikoordinir oleh seorang juragan yang umumnya adalah pedagang pengumpul.

Petani garam rakyat juga melakukan kegiatan pengemasan, dengan karung yang digunakan untuk mengemas garam rakyat. Dimana karung tersebut diberikan oleh pengumpul dengan konsekuensi biaya yang juga dibebankan kepada petani.

Karung-karung yang telah berisi garam tersebut akan ditimbang. Terdapat dua proses penimbangan yang unik di tingkat petani yaitu sistem tebas dan berdasarkan karung. Sistem tebas dilakukan dengan masing-masing petani dan pengumpul akan menimbang satu karung berukuran paling berat dan ringan kemudian dirata-ratakan. Nilai rata-rata tersebut yang akan dijadikan acuan bagi karung-karung lainnya. Sedangkan mekanisme berdasarkan karung ditetapkan berdasarkan berat karung yang diinformasikan kepada petani oleh pengumpul. Umumnya pengumpul akan menginformasikan bahwa karung tersebut berukuran $50 \mathrm{~kg}$, yang pada kenyataanya berat dari garam di karung tersebut mencapai $60 \mathrm{~kg}$.

Fungsi fasilitas yang dilakukan oleh petani responden meliputi kegiatan penanggungan risiko, pembiayaan, dan informasi pasar. Kegiatan sortasi dan grading tidak dilakukan oleh petani, karena petani hanya mampu mendiferensiasi kualitas garam berdasarkan cara konvensional yaitu dengan melihat dengan mata telanjang dan meraba butiran garam.
Kegiatan penanggungan risiko yang dilakukan petani adalah harga garam yang rendah atau dibawah harga dasar pembelian garam yang disepakati dalam peraturan pemerintah. Petani garam juga harus menanggung risiko akibat pembayaran di belakang setelah garam yang dijual pedagang pengumpul dibeli oleh pabrik garam, dengan berbagai konsekuensi yang merugikan petani.

Beberapa konsekuensi yang dibebankan adalah adanya klasifikasi garam yang tidak jelas, dimana pabrik garam tidak menerapkan penentuan kualitas berdasarkan Peraturan Dirjen Perdagangan LN mengenai penetapan kualitas. Pabrik garam melakukan pengklasifikasian kualitas garam menjadi subkualitas yaitu kualitas KP1 menjadi KP1a, KP1b dan KP3. Kondisi tersebut yang menyebabkan pengumpul menetapkan kualitas garam petani umumnya dibawah kualitas yang sebenarnya. Selain itu, petani juga menanggung biaya penyusutan yang dibebankan sebesar 5 persen dari setiap karung. Oleh karena itu, petani mengalami kondisi ketidakpastian atas garam yang dijualnya ke pengumpul akibat adanya pembayaran di belakang.

Fungsi pembiayaan yang dilakukan oleh petani adalah pembiayaan atas biaya produksi, biaya panen dan biaya pasca panen. Sedangkan fungsi informasi pasar yaitu memperoleh informasi mengenai harga garam dari sesama petani dan mengamati perkembangan harga garam rakyat yang dipantau oleh asosiasi garam rakyat. 


\section{Fungsi Pemasaran di Tingkat Pedagang Pengumpul}

Fungsi pertukaran yang dilakukan oleh lembaga tersebut adalah kegiatan pembelian dan penjualan.

Fungsi fisik yang dilakukan oleh pedagang pengumpul tersebut adalah kegiatan penyimpanan, pengangkutan dan pengemasan. Fungsi pengemasan dilakukan oleh pedagang pengumpul saat pedagang pengumpul melakukan pembelian kepada petani. Fungsi pengangkutan yang dilakukan oleh pedagang pengumpul tersebut adalah mengangkut garam rakyat dari titik pengumpul (collecting point) ke pabrik.

Fungsi fasilitas yang digunakan oleh pedagang pengumpul tersebut yaitu kegiatan grading, penanggungan risiko, pembiayaan dan informasi pasar. Kegiatan grading dilakukan oleh pedagang pengumpul apabila membeli garamnya langsung kepada petani. Fungsi penanggungan risiko yang ditanggung oleh pedagang pengumpul adalah fluktuasi harga. Fungsi pembiayaan yang dilakukan oleh pedagang pengumpul yaitu sebagian pedagang pengumpul membiayai karung dan biaya-biaya yang digunakan dalam penanganan garam rakyat. Fungsi informasi pasar yaitu pencarian informasi harga dari sesama rekan pedagang, petani ataupun ke pabrik garam.

\section{Fungsi Pemasaran di Tingkat Perantara Pabrik (Bandul)}

Pada umumnya setiap pabrik garam di Kabupaten pamekasan memiliki 1 orang perantara pabrik. Lembaga ini umumnya hanya melakukan fungsi fasilitas yaitu peminjaman nama sebagai syarat untuk dapat memasukkan garam pedagang ke pabrik garam. Peminjaman nama oleh pedagang pengumpul tersebut memberikan konsekuensi biaya yang akan diberikan kepada pengumpul. Biaya yang dibebankan tersebut sekitar Rp10.000 - Rp20.000/ton.

\section{Fungsi Pemasaran di Tingkat Pabrik Garam}

Secara Secara umum pabrik garam tersebut melakukan 3 fungsi tataniaga utama yaitu fungsi pertukaran, fungsi fisik, dan fungsi fasilitas. Fungsi pertukaran yang dilakukan oleh pabrik garam adalah kegiatan pembelian dan penjualan. Pabrik garam membeli garam bahan baku (krosok) kepada pedagang pengumpul yang melalui perantara pabrik.

Fungsi fisik yang dilakukan oleh pabrik garam meliputi kegiatan penyimpanan, manufaktur, pengangkutan dan pengemasan. Pabrik garam akan menyimpan garam rakyat yang dibelinya sebagian di dalam gudang garam yang dimiliki pabrik. Setelah itu garam yang telah disimpan tersebut kemudian langsung menuju proses pengolahan yang dimiliki perusahaan. Kegiatan pengangkutan yang dilakukan oleh pabrik garam terdiri dari kegiatan pengangkutan garam konsumsi ke lembaga pemasaran agen dan pedagang pengecer.

Fungsi fasilitas yang dilakukan oleh lembaga tersebut meliputi penanggungan risiko, pembiayaan dan informasi pasar. Penanggungan risiko yang dilakukan lembaga tersebut adalah ketidakpastian pemasaran. Kegiatan pembiayaan yang 
dilakukan oleh lembaga tersebut adalah dengan menyediakan kebutuhan modal awal baik investasi maupun variabel dan biaya-biaya yang dikeluarkan selama proses pemasaran berlangsung. Fungsi fasilitas lain yang dilakukan lembaga tersebut adalah mencari informasi pasar dengan mengamati informasi perkembangan harga baik di tingkat petani ataupun di tingkat konsumen.

\section{Fungsi Pemasaran di Tingkat Agen}

Fungsi pertukaran yang dilakukan meliputi kegiatan pembelian dan penjualan. Fungsi fisik yang dilakukan oleh lembaga ini adalah kegiatan pengangkutan. Selain itu, agen juga melakukan fungsi fasilitas berupa informasi pasar dan pembiayaan. Kegiatan pembiayaan yaitu berupa kegiatan menanggung biayabiaya dalam memasarkan produk tersebut. Sedangkan fungsi informasi pasar dilakukan agen dengan mencari informasi mengenai perkembangan harga garam beriodium di pasar.

\section{Fungsi Pemasaran di Tingkat Pedagang Pengecer}

Fungsi yang dilakukan oleh pedagang pengecer meliputi fungsi pertukaran dan fasilitas. Fungsi pertukaran yang dilakukan adalah kegiatan pembelian dan penjualan. Pembelian dari agen umumnya dalam bentuk bal dengan satu bal mempunyai berat sebesar $4 \mathrm{~kg}$ dan $8 \mathrm{~kg}$. Setiap balnya masing-masing berisi sekitar 16 buah dan 32 buah kemasan garam beriodium dengan berat bersih 250 gram. Fungsi fasilitas yang dilakukan adalah fungsi informasi pasar. Pedagang pengecer akan melakukan pencarian informasi mengenai perkembangan harga jual garam konsumsi di tingkat konsumen.

\section{IDENTIFIKASI SALURAN PEMASARAN}

Berdasarkan penelusuran di lapangan memperlihatkan bahwa pada proses penyaluran tersebut didapatkan 7 pola saluran pemasaran garam rakyat di Desa Lembung. Pola saluran pemasaran garam rakyat yang terbentuk adalah sebagai berikut:

1. Saluran I: Petani - Pedagang Pengumpul — Bandul — Pabrik Garam — Agen — Pedagang Pengecer - Konsumen

2. Saluran II: Petani - Petanipengumpul — Bandul - Pabrik Garam — Agen - Pedagang Pengecer - Konsumen

3. Saluran III: Petani - Petanipengumpul-pemilik UPG - Bandul - Pabrik Garam — Agen — Pedagang pengecer - Konsumen

4. Saluran IV: Petani-pengumpul Bandul — Pabrik Garam — Agen Pedagang Pengecer - Konsumen

5. Saluran V: Petani-pengumpul Peternak Ubur

6. Saluran VI: Petani-pengumpul Pabrik Kecap

7. Saluran VII: Petani-pengumpulpemilik UPG — Pedagang Pengecer -Konsumen

Secara keseluruhan, saluran yang terbentuk pada sistem pemasaran garam rakyat di Desa Lembung terbagi dalam 3 saluran utama. Saluran tersebut didasarkan pada titik awal penyaluran 
Tabel 1. Sebaran Volume dan Harga Pembelian Garam Rakyat Berdasarkan Lembaga Pemasaran Pembeli

\begin{tabular}{lccccc}
\hline \multirow{2}{*}{ Pembeli } & \multirow{2}{*}{$\begin{array}{c}\text { Volume } \\
(\mathbf{K g})\end{array}$} & $\begin{array}{c}\text { Persentase } \\
\mathbf{( \% )}\end{array}$ & \multicolumn{3}{c}{ Harga } \\
\cline { 4 - 6 } & 666.000 & 46.87 & 350 & 300 & 225 \\
Pedagang Pengumpul & 282.400 & 19.87 & 350 & 325 & 250 \\
Petani-pengumpul & 234.000 & 16.47 & 350 & 300 & 225 \\
Petani-pengumpul-pemilik & & & & & \\
UPG & &
\end{tabular}

garam rakyat antara lain petani, petanipengumpul, dan petani-pengumpulpemilik UPG.

\section{Saluran Tataniaga I, II, dan III}

Secara keseluruhan pada saluran pemasaran yang memiliki titik awal saluran berupa petani terbagi menjadi 3 saluran. Berdasarkan total jumlah petani responden dalam penelitian ini masingmasing sebanyak 11 orang (24.44 persen) menjual ke pedagang pengumpul, 26 orang (57.78 persen) ke petanipengumpul dan 3 orang (6.67 persen) ke petani-pengumpul-pemilik UPG. Saluran pemasaran II merupakan saluran yang paling banyak dilalui oleh petani garam di Desa Lembung. Sedangkan 5 orang petani lainnya merupakan petani yang merangkap sebagai pengumpul sebanyak 4 orang dan 1 orang sebagai pengumpul dan pemilik UPG.
Rata-rata petani responden dalam penelitian ini memberikan upah bagi pengumbal sebesar Rp25/kg. Jumlah total garam dari petani responden yang dijual ke pedagang pengumpul, petanipengumpul dan petani-pengumpulpemilik UPG masing-masing sebanyak $666.000 \mathrm{~kg}, 282.240 \mathrm{~kg}$, dan $234.000 \mathrm{~kg}$. Berdasarkan volume garam yang dijual oleh petani, saluran 1 merupakan saluran dengan volume terbesar yaitu sekitar 46.87 persen.

\section{Saluran Tataniaga IV, V, dan VI}

Secara umum ketiga saluran ini dikelompokkan berdasarkan titik awal penyaluran garam rakyat yang dimulai dari lembaga petani-pengumpul. Petanipengumpul yang menjadi responden dalam penelitian ini sebanyak 4 orang. Individu tersebut melakukan kegiatan usahatani garam yang hasilnya disalurkan ke beberapa lembaga yaitu bandul

Tabel 2. Sebaran Volume dan Persentase Garam Rakyat Berdasarkan Lembaga Pemasaran Pembeli Pada Saluran Tataniaga IV, V, dan VI

\begin{tabular}{lcc}
\hline Pembeli & Volume (Kg) & Persentase (\%) \\
\hline Bandul & 18.000 & 1,26 \\
Peternak Ubur-ubur & 18.000 & 1,26 \\
Pabrik kecap & 22.500 & 1,58 \\
\hline \multicolumn{1}{c}{ Total } & 58.500 & 4,1 \\
\hline
\end{tabular}


(saluran IV), peternak ubur-ubur (saluran V) dan pabrik kecap (saluran VI).

Petani-pengumpul yang melalui saluran 4 berjumlah 2 orang. Lembaga pemasaran yang terlibat pada saluran ini terdiri dari bandul, pabrik garam, agen dan pedagang pengecer.

Terdapat 2 orang petani-pengumpul yang menjual garamnya kepada lembaga pemasaran yang tidak menggunakan garam rakyat sebagai bahan baku utamanya. Kedua petani-pengumpul tersebut menjual garam hasil panen dari lahan tambaknya ke peternak ubur-ubur (saluran 5) dan pabrik kecap (saluran 6). Saluran 5 digunakan hanya oleh 1 orang petani-pengumpul responden. Saluran 6 juga digunakan oleh 1 orang petanipengumpul responden.

\section{Saluran Tataniaga VII}

Titik awal penyaluran garam adalah lembaga petani-pengumpul dan pemilik unit pengolahan garam. Lembaga ini mempunyai 3 peran sekaligus yaitu mengusahakan garam, menjadi pedagang pengumpul dan memiliki unit pengolahan garam.

\section{IDENTIFIKASI STRUKTUR PASAR Struktur Pasar di Tingkat Petani}

Struktur pasar yang dihadapi oleh petani garam yaitu pasar oligopsoni apabila dilihat dari sisi pembeli sedangkan dilihat dari sisi pembeli mendekati pasar sempurna. Hal ini didasarkan oleh beberapa kondisi seperti hanya terdapat beberapa pedagang pengumpul sebagai pembeli dan banyak penjual yaitu para petani garam. Kondisi jumlah petani yang lebih banyak tersebut memberikan konsekuensi yaitu petani akan bertindak sebagai penerima harga (price taker). Harga yang diterima oleh petani tersebut sudah ditentukan oleh pengumpul yang mempunyai kekuatan dalam menentukan harga beli garam. Dengak kata lain petani tidak dapat melakukan tawar-menawar harga terhadap garam yang dijualnya. Hambatan di tingkat petani relatif cukup mudah yaitu hanya terdapat pada lahan. Dimana petani baru yang akan masuk ke industri pergaraman dapat memilih alternatif penguasaan lahan yaitu menjadi petani pemilik, bagi hasil dan sewa.

Selain itu, dilihat dari sisi produk hasil panen garam yang dijual petani merupakan suatu komoditas yang relatif bersifat homogen. Informasi harga yang dimiliki oleh petani relatif cukup baik. Petani dapat saling bertukar informasi dengan sesama petani atau pedagang pengumpul yang tidak memerlukan biaya untuk mendapatkan informasi tersebut. Namun, informasi harga yang diperoleh oleh petani tersebut tidak mempengaruhi posisi tawarnya. Sehingga ada akhirnya petani tetap hanya akan bertindak sebagai penerima harga.

\section{Struktur Pasar di Tingkat Pedagang Pengumpul}

Struktur pasar di tingkat pedagang pengumpul cenderung bersifat pasar persaingan tidak sempurna (oligopsoni dilihat dari sisi pabrik garam sebagai pembeli). Hal ini disebabkan oleh adanya hambatan masuk pasar bagi para pedagang pengumpul baru. Beberapa hambatan masuk seperti adanya hubungan yang telah lama terjalin dengan 
petani baik melalui kekerabatan ataupun karena faktor lain. Kondisi bahwa hanya pedagang pengumpul yang telah dipercaya dalam waktu yang cukup lama yang dapat memungkinkan untuk mengakses pasar dan bekerja sama dengaan bandul juga menjadi hambatan masuk. Selain itu, dibutuhkan modal yang cukup besar untuk dapat menjadi pengumpul seperti untuk pembangunan gudang penyimpanan juga menjadi suatu hambatan masuk.

Selain dari sisi hambatan masuk, struktur pasar di tingkat pengumpul juga tercermin dari produk dan kesempurnaan informasi yang dimiliki oleh lembaga pemasaran. Produk yang diperdagangkan cenderung bersifat homogen meskipun garam rakyat dibedakan ke dalam beberapa grade. Selain itu pengumpul mendapatkan informasi mengenai perkembangan harga bahan baku dapat melalui sesama pedagang, maupun dari pabrik garam

\section{Struktur Pasar di Tingkat pabrik garam}

Struktur pasar yang dihadapi pabrik garam mengarah pada struktur oligopoli dan oligopsoni. Hal ini didasarkan pada jumlah pabrik garam yang lebih sedikit dibandingkan agen atau pedagang pengecer. Hambatan masuk pasar juga relatif besar yaitu dari sisi skala ekonomi usaha, dimana sebagian besar pemain atau pabrik garam merupakan perusahaan yang bermodal besar. Selain itu, hambatan tersebut juga tercermin dari pangsa pasar, kekuatan merek, adanya lisensi sertakuatnya jaringan dengan para stakeholder garam di daerah sentra garam juga menyebabkan tingginya hambatan masuk pada tingkat pabrik garam.

\section{Sistem Penentuan Harga dalam Transaksi}

Sistem penentuan harga garam rakyat di Desa Lembung dilakukan dengan proses tawar menawar dan tentu harga tersebut juga didasarkan pada musim yang terjadi pada saat transaksi. Namun demikian, keputusan akhir ditentukan oleh lembaga pemasaran yang memiliki posisi tawar lebih ntinggi. Dalam kasus sistem pemasaram garam rakyat yang memiliki posisi tawar tinggi yaitu pabrik garam dan pedagang pengumpul. Keduanya dapat mengontrol harga di tingkat petani, sedangkan pabrik garam dapat mengontrol harga secara tidak langsung ke petani melalui pedagang pengumpul. Penentuan harga di tingkat pabrik garam ditentukan oleh berbagai faktor seperti harga garam impor, jenis klasifikasi yang diterapkan pabrik tersebut dan kondisi permintaan garam di pasar.

Pedagang pengumpul menetapkan harga garam yang dibelinya dari petani berdasarkan sebagian informasi yang diperolehnya dari pabrik garam. Pada tingkat agen atau pedagang pengecer harga jual pabrik ditentukan oleh pabrik garam. Pabrik garam akan menentukan harga jualnya yang kemudian agen dan pedagang pengecer tersebut menyesuaikan harga jualnya ke konsumen akhir sesuai dengan biaya dan marjin yang ingin didapatkan.

Selain itu, pada lembaga petanipengumpul-pemilik UPG harga jual garam produksinya akan ditentukan 
sendiri oleh lembaga tersebut dengan mempertimbangkan berbagai faktor seperti biaya dan marjin yang ingin didapatkan. Lembaga tersebut akan menjual garamnya langsung ke pedagang pengecer, yang kemudian pedagang pengecer akan menjual ke konsumen akhir. Pedagang pengecer tidak dapat melakukan tawar menawar dalam hal ini karena harga akan ditentukan secara langsung oleh lembaga tersebut.

\section{Sistem Pembayaran}

Sistem pambayaran dalam transaksi garam rakyat di antara lembaga tataniaga yang terlibat pada sistem tataniaga garam rakyat dibedakan menjadi 2 yaitu secara tunai dan dibayar kemudian. Sistem pembayaran secara bayar kemudian hanya dilakukan oleh pedagang pengumpul kepada petani garam. Pada umumnya petani akan menerima pembayaran 2 hari sampai satu minggu tergantung jumlah yang akan dijual oleh pedagang pengumpul. Pada mekanisme pembayaran kemudian, petani akan sangat dirugikan akibat adanya ketidakpastian selama waktu tunggu tersebut. Sedangkan lembaga-lembaga pemasaran lainnya seperti pabrik garam, bandul, agen dan pedagang pengecer akan melakukan pembayaran secara tunai.

\section{Kerjasama Antar Lembaga}

Kerjasama yang dilakukan antara petani dan pedagang pengumpul yang terjalin selama bertahun tahun. Petani yang sama akan melakukan penjualan pada pedagang pengumpul yang sama. Selain itu, menurut informasi terdapat juga beberapa petani yang melakukan peminjaman modal usaha pada pedagang pengumpul. Kerjasama lainnya juga dilakukan oleh pedagang pengumpul dengan perantara pabrik (bandul). Adanya kerjasama-kerjasama yang dilakukan oleh lembaga-lembaga tersebut juga dapat berperan menjaga kontinuitas pasokan garam rakyat dan dapat mengurangi biaya transaksi.

\section{EFISIENSI OPERASIONAL}

\section{Efisiensi Pemasaran Garam Rakyat Kualitas KI}

Saluran tataniaga 1, 2, dan 3 memiliki total nilai marjin pemasaran yaitu Rp2.850/kg untuk saluran 1, Rp2.825/kg untuk saluran 2 dan Rp2.850 untuk saluran 3. Saluran 2 memiliki nilai farmer's share terbesar yaitu 11,72 persen. Nilai 11,72 persen ini berarti bahwa petani hanya mendapatkan sekitar 11,72 persen dari total keseluran nilai yang dibayarkan oleh konsumen akhir. Selain itu, saluran 1 dan 3 merupakan saluran dengan nilai farmer's share terkecil yaitu sebesar 10,94 persen. Saluran 3 merupakan saluran dengan nilai rasio $\pi / c$ terkecil yaitu 1,611 .

Berdasarkan kriteria indikator efisiensi yang telah dijelaskan di atas dapat disimpulkan untuk sementara bahwa garam rakyat kualitas KI relatif lebih efisien pada saluran 2. Hal ini dikarenakan nilai farmer's share yang tinggi dibandingkan dengan saluran yang lain (saluran 1 dan saluran 3) yaitu sebesar 11,72 persen. Selain itu, nilai rasio $\pi / \mathrm{c}$ sebesar 1,619 merupakan nilai yang relatif sesuai dengan kegiatankegiatan produktif yang telah dilakukan 
oleh lembaga pemasaran yang terlibat dalam saluran 2. Nilai rasio $\pi / \mathrm{c}$ yang relatif lebih tinggi dibandingkan dengan saluran 3 disebabkan total keuntungan yang lebih tinggi sebesar Rp1.894 dengan total biaya pemasaran sebesar Rp1.169,308.

Saluran 4 memberikan marjin sebesar 3.063.44, nilai farmer's share sebesar 13,75 dan nilai rasio $\pi / \mathrm{c}$ sebesar 1,62. Ketiga nilai indikator tersebut merupakan yang terbesar dibandingkan dengan saluran lainnya. Namun nilai farmer's share tersebut memiliki pengertian yang berbeda jika dibandingkan dengan saluran 1, 2 dan 3. Saluran 4 juga tidak dapat secara langsung dibandingkan dengan saluran 5 dan 6 .

Saluran 5 memberikan nilai marjin sebesar Rp313.44, nilai farmer's share sebesar 100 persen dan rasio $\pi / \mathrm{c}$ sebesar 0,6 . Pada saluran 6 memberikan nilai marjin sebesar Rp513,44, nilai farmer's share sebesar 100 persen dan nilai rasio $\pi /$ c sebesar 1,62. Berdasarkan indikator efisiensi operasional dapat disimpulkan bahwa saluran 6 merupakan saluran yang relatif lebih efisien dibandingkan dengan saluran 5

Pada saluran 7 memberikan nilai marjin pemasaran sebesar Rp1.963, nilai farmer's share sebesar 90,48 persen dan nilai rasio $\pi / \mathrm{c}$ sebesar 0,4 . Nilai dari indikator-indikator efisiensi tersebut merupakan yang terbesar apabila dibandingkan dengan saluran yang melakukan proses pengolahan garam menjadi garam beryodium. Namun saluran 7 tidak memungkinkan untuk dibandingkan dengan saluran-saluran yang lain, akibat perbedaan titik awal penyaluran tersebut. Lebih jelasnya dapat dilihat di lampiran 1 .

\section{Efisiensi Pemasaran Garam Rakyat Kualitas KII}

Saluran pemasaran yang memiliki nilai marjin terbesar adalah saluran 3 yaitu sebesar Rp2.900 / kg. Saluran pemasaran 1 dan 2 memiliki nilai marjin pemasaran yang sama yaitu sebesar $\mathrm{Rp}$ $2.875 / \mathrm{kg}$, sedangkan saluran 4 memiliki nilai marjin sebesar Rp3.063,44/kg. Saluran 7 memiliki nilai marjin sebesar Rp1.963/kg dan nilai marjin tersebut merupakan nilai marjin yang terkecil dibandingkan dengan saluran lainnya. Selain itu, masing-masing saluran memiliki nilai farmer's share yang berbedabeda yaitu secara berturut-turut sebesar 10,16 persen untuk saluran 1; 10,94 persen untuk saluran $2 ; 9,38$ persen untuk saluran $3 ; 12,19$ persen untuk saluran 4; dan 90,48 persen untuk saluran 7 .

Saluran 2 dinilai lebih efisien daripada marjin tataniaga yang dihasilkan oleh saluran lainnya (1 dan 3). Hal ini karena pada saluran 2 terdapat banyak kegiatan produktif yang tercermin pada besaran nilai total biaya pemasaran yaitu sebesar Rp1.201.88/kg. Selain itu, nilai farmer's share saluran 2 merupakan nilai farmer's share terbesar yaitu 10,94 persen. Total nilai rasio $\pi / \mathrm{c}$ untuk saluran 2 merupakan juga yang terbesar yaitu sebesar 1,569. Lebih jelasnya dapat dilihat di lampiran 2.

\section{Efisiensi Pemasaran Garam Rakyat Kualitas KIII}

Saluran 1, saluran 2 dan saluran 3 masing-masing memiliki nilai marjin 
sebesar Rp2.975/kg, Rp2.950/kg dan Rp2.925/kg. Saluran 4 memiliki nilai total marjin sebesar 3.063.44 dan sebesar Rp1.963/kg untuk saluran 7. Masingmasing saluran tersebut memiliki nilai farmer's share yang berbeda yaitu secara berturut-turut sebesar 7,03 untuk saluran 1; 7,81 untuk saluran 2, 8,59 untuk saluran 3; dan 9,84 untuk saluran 4 dan sebesar 90,48 untuk saluran 7, sehingga saluran yang memiliki nilai farmer's share terbesar adalah saluran 3. Nilai farmer's share yang besar tersebut dipengaruhi oleh besarnya harga jual yang diterima petani. Selain itu, saluran 3 juga mempunyai nilai rasio $\pi / \mathrm{c}$ terbesar yaitu 1,519. Jadi berdasarkan berbagai indikator efisiensi operasional dapat diambil kesimpulan sementara bahwa saluran tataniaga 3 relatif lebih efisien untuk kualitas KIII. Lebih jelasnya dapat dilihat di lampiran 3

\section{IMPLIKASI EFISIENSI PEMASARAN GARAM RAKYAT}

Penetapan kriteria efisien pemasaran dengan mempertimbangkan variabel kualitatif dan kuantitatif dalam penelitian ini hanya didasarkan pada saluran yang dilalui oleh petani murni (saluran 1, 2 dan 3). Hal ini dikarenakan hampir 95 persen petani responden menggunakan ketiga saluran tersebut. Oleh karena itu, berdasarkan kedua analisis tersebut (kuantitatif dan kualitatif) dapat disimpulkan bahwa pemasaran garam rakyat di Desa Lembung belum efisien. Beberapa alasan yang mendasarinya adalah sebgai berikut:

1. Lemahnya posisi tawar petani menyebabkan petani tidak memiliki andil dalam penetapan harga dan mutu atau sebagai penerima harga

2. Penetapan kualitas garam yang tidak transparan sangat memberatkan petani dan adanya penyimpangan klasifikasi menjadi subklasifikasi yang ditetapkan oleh pabrik garam.

3. Proses penimbangan karung garam yang cenderung tidak adil

4. Mekanisme pembayaran kemudian oleh pengumpul yang menimbulkan ketidakpastian dan cenderung merugikan petani.

5. Harga dasar garam yang ditetapkan oleh pemerintah tidak berlaku di lapangan.

6. Besarnya marjin pemasaran dan kecilnya nilai farmer's share yang terbentuk dalam saluran pemasaran.

Fakta-fakta di lapangan tersebut merupakan bukti bahwa terjadi ketidakadilan yang dialami oleh petani garam. Oleh karena itu, peran para stakeholder terutama pemerintah sangat dibutuhkan untuk melakukan kontrol dan melakukan inisisasi untuk memberdayakan petani khususnya untuk meningkatkan kekuatan posisi tawar. Hal ini didasarkan pada fakta bahwa permasalahan utama dalam proses pemasaran garam rakyat terletak pada rendahnya posisi tawar yang dimiliki petani.

Adanya peran kelompok tani yang aktif diharapkan dapat meningkatkan posisi tawar petani terutama dalam mengakses pasar yang menguntungkan petani, sehingga meningkatkan harga jual garam. Alternatif pembentukan kelompok tani ini berdasarkan Nasution (1999) yang menyatakan bahwa kemampuan usaha kecil dapat diberdayakan melalui 
kegiatan lembaga kelompk tani/ koperasi untuk penguatan kemampuan bersaing melalui kerjasama. Dengan kebersamaan seperti itu akan dapat diwujudkan "economic of scale" serta "economic of scope" yang menekan besarnya komponen biaya.

Terbentuknya kelompok tani minimal diharapkan dapat mengadopsi fungsi yang dilakukan oleh pengumpul. Namun untuk meminimalisir adanya konflik, kelompok tani yang terbentuk diharapkan juga memasukkan petani-pengumpul dan pedagang pengumpul menjadi anggota kelompok tani. Bahkan dengan meningkatkan jumlah anggota kelompok tani yang aktif dapat sekaligus meningkatkan posisi tawarnya terhadap pabrik garam.

Pada penelitian ini, saluran 4, 5, 6 dan 7 hanya dijadikan sebagai pembanding untuk skenario saluran pemasaran bagi petani. Kondisi tersebut dimungkinkan apabila petani telah membentuk kelompok tani dan mengadopsi peran pengumpul. Dengan kata lain, kelompok tani yang telah terbentuk diharapkan dapat mengumpulkan hasil garam petani kemudian menjualnya ke lembaga pabrik atau perantara pabrik. Oleh karena itu, dengan asumsi struktur biaya pada saluran skenario tersebut tetap, maka petani juga diharapkan akan mendapatkan keuntungan dengan mengambil alih nilai tambah dari proses pada saluran pemasaran tersebut.

\section{SIMPULAN}

Berdasarkan hasil penelitian sistem pemasaran garam rakyat di Desa Lembung, Kecamatan Galis Kabupaten Pamekasan, Jawa Timur pada Bulan
Oktober-November 2013 dapat diperoleh simpulan sebagai berikut:

1. Penyaluran garam rakyat di Desa Lembung dibagi kedalam 3 saluran utama yang didasarkan pada titik awal penyaluran. Saluran 1, 2, dan 3 merupakan saluran yang titik awal penyaluran dimulai pada tingkat petani. Saluran 4, 5, dan 6 merupakan saluran yang titik awalnya dimulai tingkat petani-pengumpul. Saluran 7 merupakan saluran yang titik awalnya dimulai pada tingkat petanipengumpul-pemilik UPG. Lembaga pemasaran yang terlibat pada pemasaran garam rakyat di Desa Lembung terdiri dari pedagang pengumpul, perantara pabrik, pabrik garam, agen dan pedagang pengecer. Lembaga-lembaga tersebut melakukan fungsi pemasaran yang berbedabeda.

2. Struktur pasar yang dihadapi pada masing-masing lembaga pemasaran berbeda-beda. Pada tingkat petani garam cenderung mengarah pada pasar oligopsoni. Sturktur pasar yang dihadapi oleh pedagang pengumpul dan petani-pengumpul cenderung bersifat oligopsoni. Struktur pasar yang cenderung oligopsoni juga dihadapi oleh pabrik garam, perantara pabrik, agen dan pedagang pengecer. Berdasarkan struktur pasar yang terbentuk tersebut akan membentuk pola prilaku pasar yang menyesuaikan dengan struktur pasar yang dihadapi.

3. Berdasarkan indikator analisis efisiensi operasional dan indikator kualitatif menunjukkan bahwa sistem pemasaran (saluran 1, 2, dan 3) yang 
terbentuk belum efisien. Hal tersebut terjadi karena petani masih memiliki posisi tawar yang rendah sehingga hanya berperan sebagai penerima harga. Adanya ketidakadilan yang dialami petani pada pemasaran garam rakyat juga menjadi alasan mengapa saluran tersebut tidak efisien. Akan tetapi diantara 3 saluran tataniaga dengan titik awal petani, saluran 2 rata-rata untuk semua kualitas merupakan saluran yang relatif lebih efisien dibandingkan dengan saluran lainnya. Sedangkan saluran 4, 5, 6, dan 7 tidak dilakukan pembandingan efisiensi karena keempat saluran tersebut digunakan sebagai pembanding rekomendasi skenario saluran tataniaga yang efisien. Hal ini disebabkan bahwa pada keempat saluran tersebut titik awal penyaluran tidak dimulai pada tingkat petani.

\section{SARAN}

1. Pemerintah sebaiknya mulai lebih memperhatikan kondisi petani garam rakyat khususnya pendapatannya yang rendah melalui fungsi pengawasan yang ditujukan terhadap sistem pemasaran garam rakyat. Karena selama ini pemerintah hanya memusatkan perhatiannya pada level usahatani yaitu dengan melaksanakan pemberdayaan petani garam rakyat melalui bantuan hibahnya (PUGAR). Namun dilapangan permasalahan pelik pada bidang penggaraman terpusat pada sistem pemasaran yaitu adanya ketidakadilan pasar yang dihadapi petani garam rakyat. Selian itu, pemerintah diharapkan dapat mampu mengawasi jalannya peraturan pemerintah pusat mengenai penetapan harga jual garam.

2. Pemerintah sebaiknya dapat melakukan pemberdayaan peran kelompok tani. Selain itu adanya kelompok tani diharapkan dapat memanfaatkan peluang yang ada dalam sistem pemasaran garam rakyat untuk mencari alternatif penjualan yang lebih menguntungkan. Kelompok tani juga diharapkan mampu bekerja secara optimal dan melakukan pemasaran terhadap lembaga pemasaran yang lebih menguntungkan. Selain itu, diharapkan pemerintah melakukan pendampingan bagi kelompok tani yang baru terbentuk tersebut dalam hal permodalan, pengawasan pemberian hibah dan lain-lain.

3. Untuk penelitian selanjutnya, diharapkan dapat menganalisis pendapatan usahatani untuk memberikan gambaran yang lebih riil mengenai pendapatan petani garam dan perlu juga dilakukan pengkajian efisiensi harga untuk mengetahui keterpaduan (integrasi) harga garam rakyat atau melalui pendekatan analisis market channel choice.

\section{DAFTAR PUSTAKA}

Asmarantaka, R W. 2012. Pemasaran Agribisnis (Agrimarketing). Bogor (ID): Institut Pertanian Bogor.

Dahl, D. C and J. W. Hammond. 1977. Market and price Analysis The Agricultural Industries, Mc Graw,. Hill Book Company. Newyork. 
Kementerian Kelautan dan Perikanan (KKP). 2010. Kelautan dan Perikanan Dalam Angka 2010. Pusat Data Statistik dan Informasi (Pusdatin), Kementerian Kelautan dan Perikanan. Jakarta.

KKP. 2011. Industrialisasi Usaha Garam Rakyat. Jakarta (ID):KKP

KKP. 2013. Neraca Garam Nasional 2011. Jakarta: Direktorat KP3K. Kementerian Kelautan dan Perikanan RI.

Limbong, W.M dan P. Sitorus. 1987. Pengantar Tataniaga Pertanian. Bahan Kuliah. Jurusan Ilmu-ilmu Sosial Ekonomi Pertanian. Fakultas Pertanian. Institut Pertanian Bogor. Bogor

Mukhtar. 2009. Garis Pantai Indonesia Terpanjang Keempat di Dunia (terhubung berkala). http://www.kkp.go.id/index.php/ar sip/c/1048/Garis-PantaiIndonesia-Terpanjang-Keempatdi-Dunia/. [28 Februari 2013]

Nasution, M.1999. Koperasi: Konsepsi, Pemikiran dan Peluang Pembangunan Masa Depan Bangsa. Departemen Kehutanan dan Perkebunan RI. Jakarta.

Rochwulaningsih Y. 2013. Tata Niaga Garam Rakyat dalam Kajian Struktural. Jurnal Sejarah CITRA LEKHA. Vol.18 p.59-66

Suherman T, Fauziah E dan Hasan F. 2011. Analisis Pemasaran Garam Rakyat (Studi Kasus Desa Kertasada, Kecamatan Kalianget, Kabupaten Sumenep). Jurnal EMBRYO. Vol 8. No 2
Widiarto. 2012. Kajian Efektivitas Implementasi Program Pemberdayaan Usaha Garam Rakyat di Desa Losarang, Kabupaten Indramayu. Thesis. Program Magister Profesional Industri Kecil Menengah. Sekolah Pascasarjana. IPB. Bogor. 
Lampiran 1. Efisiensi Pemasaran Garam Rakyat Kualitas KI di Desa Lembung

\begin{tabular}{lrrr}
\hline $\begin{array}{c}\text { Saluran } \\
\text { Pemasaran }\end{array}$ & $\begin{array}{c}\text { Marjin } \\
\text { Pemasaran }\end{array}$ & Farmer's Share & Rasio $\boldsymbol{\pi} / \mathbf{c}$ \\
\hline Saluran 1 & 2850 & 10.94 & 1.632 \\
Saluran 2 & 2825 & 11.72 & 1.619 \\
Saluran 3 & 2850 & 10.94 & 1.611 \\
Saluran 4 & 3063.44 & 13.75 & 1.620 \\
Saluran 5 & 313.44 & 100.00 & 0.600 \\
Saluran 6 & 513.44 & 100.00 & 1.080 \\
Saluran 7 & 1963.00 & 90.48 & 0.400 \\
\hline
\end{tabular}

Lampiran 2. Efisiensi Pemasaran Garam Rakyat Kualitas KII di Desa Lembung

\begin{tabular}{lrrr}
\hline $\begin{array}{c}\text { Saluran } \\
\text { Tataniaga }\end{array}$ & $\begin{array}{c}\text { Marjin } \\
\text { Tataniaga }\end{array}$ & Farmer's Share & Rasio $\boldsymbol{\pi} / \mathbf{c}$ \\
\hline Saluran 1 & 2875 & 10.16 & 1.549 \\
Saluran 2 & 2875 & 10.94 & 1.569 \\
Saluran 3 & 2900 & 9.38 & 1.528 \\
Saluran 4 & 3063.44 & 12.19 & 1.549 \\
Saluran 7 & 1963.00 & 90.48 & 0.400 \\
\hline
\end{tabular}

Lampiran 3. Efisiensi Pemasaran Garam Rakyat Kualitas KIII di Desa Lembung

\begin{tabular}{lrrr}
\hline $\begin{array}{c}\text { Saluran } \\
\text { Pemasaran }\end{array}$ & $\begin{array}{c}\text { Marjin } \\
\text { Pemasaran }\end{array}$ & Farmer's Share & Rasio $\boldsymbol{\pi} / \mathbf{c}$ \\
\hline Saluran 1 & 2975 & 7.03 & 1.475 \\
Saluran 2 & 2950 & 7.81 & 1.499 \\
Saluran 3 & 2925 & 8.59 & 1.519 \\
Saluran 4 & 3063.44 & 9.84 & 1.499 \\
Saluran 7 & 1963.00 & 90.48 & 0.400 \\
\hline
\end{tabular}

